\title{
Førstehånds, førstevalg eller førstelinje?
}

\author{
Hva er et førstelinjemedikament? Det første legemidlet som forsøkes eller et middel som gis i førstelinje- \\ tjenesten?
}

Uttrykkene førstehåndsmiddel eller førstevalgsmiddel brukes gjerne om det medikamentet som legen velger først ved en gitt tilstand. På engelsk heter det first-line (agent, drug etc.), og det oversettes iblant direkte med førstelinjemiddel eller førstelinjemedikament. De tre begrepene førstehånds-, førstevalgs- og førstelinjemiddel brukes altså om det samme.

\section{Førstelinjetjenesten $=$ primærhelsetjenesten}

Førstelinjetjenesten er den delen av helsevesenet som drives på lokalt nivå og som pasientene kan vende tilbake til (1). Kommunehelsetjeneste eller primærhelsetjeneste dekker det samme. Det er derfor forståelig at førstelinjemiddel gir assosiasjoner til allmennpraksis - et middel som forskrives i primærhelsetjenesten. Men slik er det altså ikke. Førstelinjemiddel omfatter noe annet: Det er et medikament som forsøkes først, før man ev. går i gang med andre midler (2). Nå vil jo de to betydningene delvis overlappe. Mange medikamentbehandlinger settes ofte i gang først i primærhelsetjenesten - men langt fra alle.

På samme måte kunne man tro at førstelinjebehandling betegner behandling som gis i primærhelsetjenesten. Men det stemmer heller ikke. Et søk i Tidsskriftets nettutgave gir 43 treff på førstelinjebehandling (27.4.2012). Flertallet omhandler onkologisk behandling.

\section{I praksis}

Et søk på tidsskriftet.no gir 33 treff på førstehåndsmiddel/førstehåndsmedikament/ førstehåndspreparat, 23 treff på førstevalgsmiddel/førstevalgsmedikament/førstevalgspreparat og ti treff på førstelinjemedikament/førstelinjepreparat (entalls- og flertallsformer) (27.4.2012). Også et søk på verdensveven gir flest treff på «førstehånds». Denne ordbruken har lang tradisjon på norsk.

Ifølge Steinar Madsen i Statens legemiddelverk er det en del begrepsforvirring når det gjelder disse ordene. Legemiddelverket bruker som oftest førstevalg/andrevalg, førstehånds/andrehånds eller første alternativ/andre alternativ i sin informasjon. Når man har mange alternative medikamenter, blir det nok litt rart å bruke ordene

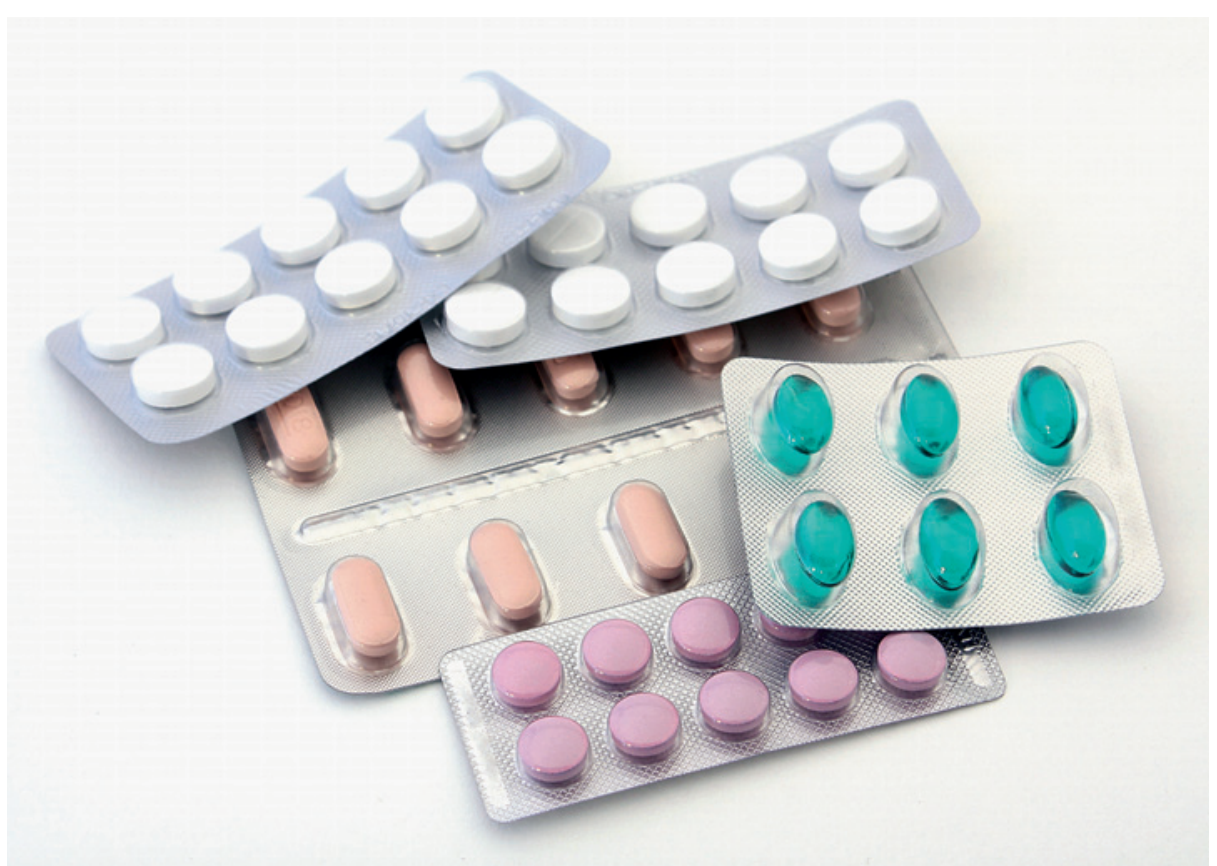

Illustrasjonsfoto Thinkstock photo

«tredjehånds» og «fjerdehånds», da vil «tredje valg» eller «tredje alternativ» klinge bedre (S. Madsen, personlig meddelelse). I en del tilfeller vil det passe best med omskrivninger, slik som første medikament$\operatorname{valg}(3)$ etc.

\section{Konklusjon}

Det kan rydde misforståelser av veien hvis «førstelinje» ble reservert for helsevesenets nivåer, og at begrep som førstehåndsmiddel eller førstevalgsmiddel brukes når medikamenter skal grupperes. Men det spørs om en slik distinksjon lar seg opprettholde. Det er flere motkrefter: Det engelske first-line drug vil øve påtrykk på norsk og lett bli oversatt med førstelinjemiddel. Dessuten er førstelinjebehandling tydeligvis etablert som betegnelse på initialbehandling uavhengig av helsetjenestenivå, og bryter med ideen om å reservere førstelinje for primærhelsetjenesten.

Legemiddelverkets praksis er entydig, og i Tidsskriftet vil vi derfor foretrekke førstevalg/andrevalg, førstehånds/andrehånds eller forste alternativ/andre alternativ i beskrivelsen av legemiddelalternativer.

\section{Erlend Hem}

erlend.hem@medisin.uio.no

Geir W. Jacobsen

Tidsskriftet

Vi takker Are Brean for hjelp med manuskriptet.

Erlend Hem (f. 1970) er dr.med. og assisterende redaktør i Tidsskriftet.

Geir W. Jacobsen (f. 1945) er professor ved Institutt for samfunnsmedisin, Norges teknisknaturvitenskapelige universitet og medisinsk redaktør i Tidsskriftet.

Litteratur

1. Øyri A. Norsk medisinsk ordbok. 9. utg. Oslo: Samlaget, 2011: 361.

2. First or second line. I: Therapy. Wikipedia. http://en.wikipedia.org/wiki/

Therapy\#First_or_second_line (27.4.2012).

3. Mørch K, Myrvang B. Medikamentell behandling av malaria i Norge. Tidsskr Nor Legeforen 2012; 132: $664-7$. redaktør Raida Ødegaard. 